\title{
Erythrocyte-binding assays reveal higher binding of Plasmodium knowlesi Duffy binding protein to human $\mathrm{Fy}^{\mathrm{a} / \mathrm{b}+}$ erythrocytes than to $\mathrm{Fy}^{\mathrm{a}+\mathrm{b}-}$ erythrocytes
}

\author{
Mun Yik Fong ${ }^{* \dagger}$ (D), Fei Wen Cheong ${ }^{\dagger}$ and Yee Ling Lau
}

\begin{abstract}
Background: The merozoite of the zoonotic Plasmodium knowlesi invades human erythrocytes via the binding of its Duffy binding protein (PkDBPall) to the Duffy antigen on the eythrocytes. The Duffy antigen has two immunologically distinct forms, Fy and Fy ${ }^{b}$. In this study, the erythrocyte-binding assay was used to quantitatively determine and compare the binding level of PkDBPall to $\mathrm{Fy}^{\mathrm{a}+/ \mathrm{b}+}$ and $\mathrm{Fy}^{\mathrm{a}+/ \mathrm{b}-}$ human erythrocytes.

Results: In the erythrocyte-binding assay, binding level was determined by scoring the number of rosettes that were formed by erythrocytes surrounding transfected mammalian COS-7 cells which expressed PkDBPall. The assay result revealed a significant difference in the binding level. The number of rosettes scored for Fy ${ }^{\mathrm{a}+/ \mathrm{b}+}$ was 1.64 -fold higher than that of $\mathrm{Fy}^{\mathrm{a}+/ \mathrm{b}-}\left(155.50 \pm 34.32\right.$ and $94.75 \pm 23.16$ rosettes, respectively; $\left.\mathrm{t}_{(6)}=-2.935, P=0.026\right)$.

Conclusions: The erythrocyte-binding assay provided a simple approach to quantitatively determine the binding level of PkDBPall to the erythrocyte Duffy antigen. Using this assay, PkDBPall was found to display higher binding to Fy ${ }^{a+/ b+}$ erythrocytes than to $\mathrm{Fy}^{\mathrm{a}+\mathrm{b}-}$ erythrocytes.
\end{abstract}

Keywords: Plasmodium knowlesi, Duffy binding protein, Duffy antigen, Erythrocyte-binding assay

\section{Background}

Almost 15 years ago, Plasmodium knowlesi, a malaria parasite of long-tailed and pig-tailed macaques in Southeast Asia, was reported to cause a high number of human infections in Sarawak on Borneo Island [1]. Since this landmark report, human knowlesi malaria has been encountered in other parts of Borneo Island, Peninsular Malaysia, all countries in Southeast Asia, the Andaman and Nicobar Islands of India, and southwest China [2, 3]. In addition, knowlesi malaria has been reported in ecotourism travellers from the USA, Europe, the Far East and Australasia, who visited the forests of Southeast Asia [4]. Hitherto, more than 4000 cases of human knowlesi malaria have been reported in Malaysia and P. knowlesi has overtaken Plasmodium vivax

\footnotetext{
* Correspondence: fongmy@um.edu.my

${ }^{+}$Mun Yik Fong and Fei Wen Cheong contributed equally to this work.

Department of Parasitology, Faculty of Medicine, University of Malaya, Kuala Lumpur, Malaysia
}

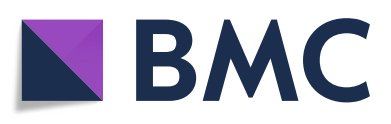

(c) The Author(s). 2018 Open Access This article is distributed under the terms of the Creative Commons Attribution 4.0 International License (http://creativecommons.org/licenses/by/4.0/), which permits unrestricted use, distribution, and reproduction in any medium, provided you give appropriate credit to the original author(s) and the source, provide a link to the Creative Commons license, and indicate if changes were made. The Creative Commons Public Domain Dedication waiver (http://creativecommons.org/publicdomain/zero/1.0/) applies to the data made available in this article, unless otherwise stated.

(a human malaria parasite) as the main cause of malaria in the country.

Invasion of the malaria parasite merozoite into its host erythrocyte is a multi-step process. It starts with the attachment of the merozoite to the erythrocyte surface, followed by apical reorientation of the merozoite, formation of a tight-junction between the cellular membrane of the merozoite and erythrocyte, and entry of the merozoite into the erythrocyte cytosol to form a parasitophorous vacuole, within which the parasite grows and replicates [5]. The tight-junction formation is a key step of the invasion, and it involves interaction between the merozoite's binding protein and its corresponding receptor on the surface of the erythrocyte. In the case of $P$. knowlesi, the interaction occurs between its Duffy binding protein $(\mathrm{PkDBP})$ and the erythrocyte's Duffy antigen receptor for chemokines (DARC) [6]. PkDBP is a large protein and can be divided into seven regions (I-VII). The amino acid motifs for binding to the 
erythrocyte DARC reside in region II. PkDBP is encoded by an $\alpha$-gene and therefore region II is known as PkDBP $\alpha$ II. The human erythrocyte Duffy (Fy) antigen has two immunologically distinct forms. These forms, known as $\mathrm{Fy}^{\mathrm{a}}$ and $\mathrm{Fy}^{\mathrm{b}}$, are the result of a single amino acid substitution [7] in the domain that binds with PkDBPoII.

Similar to P. knowlesi, P. vivax also uses the Duffy antigen receptor to invade erythrocytes. Recent studies have shown that $\mathrm{Fy}^{\mathrm{a}}$, compared with $\mathrm{Fy}^{\mathrm{b}}$, significantly reduced the binding of $P$. vivax Duffy binding protein (PvDBP) at the erythrocyte surface. Interestingly, this is associated with a reduced risk of vivax malaria in humans [8]. A limited number of studies have been carried out to measure and compare the binding level of PkDBP to the Fy antigen. A study conducted in the late 1980s indicated greater binding of a $135 \mathrm{kD}$ protein, presumably $\mathrm{PkDBP}$, to $\mathrm{Fy}^{\mathrm{b}}$ than to $\mathrm{Fy}^{\mathrm{a}}$ [9]. However, the experiments in the study used metabolically labeled proteins in the supernatant of in vitro cultured P. knowlesi, and the binding activity was qualitatively determined by probing the $135 \mathrm{kD}$ protein with in situ erythrocytes and electrophorectically-separated erythrocyte proteins on blots.

The in vitro erythrocyte-binding assay is widely used in studies on binding activity between malaria parasites' erythrocyte binding proteins and their corresponding receptors on the host erythrocyte. In this assay, the protein of interest is heterologously expressed on the surface of mammalian cells. Erythrocytes are added to the cells and positive binding is shown by the formation of rosettes, which are aggregates of erythrocytes surrounding cells expressing the protein. The advantage of this assay is that binding level can be quantitatively determined by counting the number of rosettes [10-12]. Hence in the present study, this assay was used to compare the binding level of PkDBP $\alpha I$ to $\mathrm{Fy}^{\mathrm{a}+/ \mathrm{b}-}$ and $\mathrm{Fy}^{\mathrm{a}+/ \mathrm{b}+}$ erythrocytes, the two common Duffy phenotypes in the Malaysian population.

\section{Methods}

\section{Construction of recombinant plasmid PkDBPall for a} eukaryotic expression system

Construction of recombinant plasmid PkDBPaII for a eukaryotic expression system was performed as previously described [12]. Briefly, the PkDBP $\alpha I$ gene was amplified from the P. knowlesi genomic DNA extracted from patient blood by PCR, and then cloned into PCR vector pGEMT $^{\bullet}$ (Promega Corp, Wisconsin, USA). Recombinant PkDBP $\alpha I I-$ pEMT $^{\odot}$ plasmid was digested using restriction enzyme $B g l \mathrm{II}$ and cloned into the eukaryotic expression vector pDisplay ${ }^{\text {Tw }}$ (with fluorescent reporter gene GFP at the C-terminus) via multiple cloning steps. The recombinant PkDBP $\alpha I I-p D i s p l a y{ }^{\text {mix }}$ plasmid was extracted and the concentration of the plasmid was determined prior to transfection into COS-7 mammalian cells.

\section{Expression of PkDBPall on COS-7 mammalian cells}

COS-7 $\left(\right.$ ATCC $^{\circ}$ CRL-1651 $^{\mathrm{mm}}$ ) cells were grown in a $5 \%$ $\mathrm{CO}_{2}$ incubator at $37{ }^{\circ} \mathrm{C}$ using DMEM (Thermo Fisher Scientific, Waltham, Massachusetts, USA) complete medium supplemented with $1 \%$ penicillin-streptomycin and $10 \%$ fetal bovine serum (FBS). Prior to transfection, the COS-7 cells were plated into 6-well culture plates. When the cells reached $>90 \%$ confluency, transfection was performed with $2.5 \mu \mathrm{g}$ of PkDBP $\alpha I I-p D i s p l a y^{\mathrm{Tm}}$ plasmid DNA using Lipofectamine 3000 reagent (Invitrogen, Carlsbad, CA, USA). Serum-free DMEM incomplete medium was used during transfection and the cells were grown in a $5 \% \mathrm{CO}_{2}$ incubator at $37{ }^{\circ} \mathrm{C}$. At $24 \mathrm{~h}$ post-transfection, the culture medium was replaced with DMEM complete medium containing 10\% FBS, and the cells were further incubated for another $24 \mathrm{~h}$. These transfected COS-7 cells were then used in the erythrocyte-binding assay.

\section{Detection of rosette formation in the erythrocyte-binding assay}

Blood donors were selected and the Duffy genotype of their erythrocytes was confirmed using allelic specific PCR (ASP-PCR) as previously described [13]. One day before the assay, erythrocytes were collected from the blood donors. The erythrocytes were washed 3-4 times with incomplete DMEM and the washed erythrocytes were stored at $4{ }^{\circ} \mathrm{C}$ prior to use. At $48 \mathrm{~h}$ post-transfection, PkDBP $\alpha I$ protein was expected to be expressed on the surface of the COS-7 cells. Washed erythrocytes were diluted to $1 \%$ haematocrit using incomplete DMEM and added into wells with transfected COS-7 cells, followed by $2 \mathrm{~h}$ incubation at $37{ }^{\circ} \mathrm{C}$. Erythrocytes were discarded and the wells were washed 3 times with $1 \times$ PBS to remove non-binding erythrocytes. The wells were incubated with $1 \mu \mathrm{g} / \mathrm{ml}$ Hoechst 33342 dye (Invitrogen) for $1 \mathrm{~min}$ in darkness to stain the nuclei of COS-7 cells. After three washes with $1 \times$ PBS, $1 \%$ paraformaldehyde was added and incubated at room temperature for $10 \mathrm{~min}$ to stabilize the rosettes. All washes were carried out in a gentle manner to prevent formed rosettes from being dislodged. Nikon Eclipse TE300 inverted fluorescence microscope was used to observe the successfully transfected COS-7 cells under a FITC-filter (488 $\mathrm{nm}$ excitation wavelength) and to determine the number of rosettes. Rosettes were counted as positive when adherent erythrocytes covered more than $50 \%$ of the COS- 7 cell surface $[10,11]$, whereas binding was scored as negative when no rosette was observed in the entire well. The number of rosettes in 30 fields at a 
magnification of $200 \times$ was counted to score the binding. Four $\mathrm{Fy}^{\mathrm{a}+\mathrm{b}-}$ and four $\mathrm{Fy}^{\mathrm{a} / \mathrm{b}+}$ blood samples were used in the assay. Triplicates were performed for each blood sample. COS-7 cells transfected with plasmid without insert were used as negative control.

\section{Statistical analysis}

The erythrocyte-binding assay results of the $\mathrm{Fy}^{\mathrm{a}+\mathrm{b}+}$ and $\mathrm{Fy}^{\mathrm{a}+\mathrm{b}-}$ erythrocytes $(n=4$ for each group) were analysed using SPSS v.20 statistical software (IBM, Chicago, Illinois, USA). A Shapiro-Wilk test was used to determine normality. An independent t-test was used to compare the mean difference of $\mathrm{Fy}^{\mathrm{a}+\mathrm{b}+}$ and $\mathrm{Fy}^{\mathrm{a}+/ \mathrm{b}-}$ erythrocytes. The difference was considered significant when $P<0.05$. Cohen's d-test was used to determine the effect size.

\section{Results}

PkDBPaII was successfully amplified and cloned into eukaryotic expression vector $\mathrm{pDisplay}^{\mathrm{rm}}$. The recombinant plasmid was successfully transfected into COS-7 cells. Figure 1 shows PkDBPaII protein expression on COS-7 cells $48 \mathrm{~h}$ post-transfection (viewed with green fluorescence under a FITC-filter). In the negative control (COS-7 cells transfected with pDisplay ${ }^{\mathrm{mi}}$ plasmid without the PkDBPaII gene) no green fluorescence was observed. The Duffy grouping of blood donors' erythrocytes was confirmed by ASP-PCR. The amplification product of
713 bp was yielded for both $\mathrm{Fy}^{\mathrm{a}}$ and $\mathrm{Fy}^{\mathrm{b}}$ alleles. Four samples each for phenotypes $\mathrm{Fy}^{\mathrm{a}+\mathrm{b}-}$ and $\mathrm{Fy}^{\mathrm{a}+/ \mathrm{b}+}$ were selected for the erythrocyte-binding assay.

The Shapiro-Wilk test showed that the rosette number scores for the four samples were normally distributed, hence an independent $\mathrm{t}$-test was used to compare the mean difference between the binding level of $\mathrm{Fy}^{\mathrm{a}+/ \mathrm{b}-}$ and $\mathrm{Fy}^{\mathrm{a}+\mathrm{b}+}$ to $\mathrm{PkDBP} \alpha \mathrm{II}$. The result revealed a significant difference in the binding level. The number of rosettes scored for $\mathrm{Fy}^{\mathrm{a}+\mathrm{b}+}$ was 1.64-fold higher than that of $\mathrm{Fy}^{\mathrm{a}+\mathrm{b}-}(155.50 \pm 34.32$ and $94.75 \pm 23.16$ rosettes, respectively; $t_{(6)}=-2.935, P=0.026$ ) (Table 1 ). The Cohen's d effect size value was 2.075 , indicating the effect size was large and the means of the two groups differed more than 2 standard deviations. No rosette was observed in the negative control wells, indicating no binding of erythrocytes to the COS-7 cells transfected with empty plasmid.

\section{Discussion}

The Duffy antigen plays a key role in the invasion process of $P$. knowlesi and $P$. vivax into the human erythrocyte. The two major forms of the antigen, $\mathrm{Fy}^{\mathrm{a}}$ and $\mathrm{Fy}^{\mathrm{b}}$, have been shown to have different binding levels to P. vivax PvDBPII. Direct binding and antibody inhibitory binding experiments revealed decreased $\mathrm{Fy}^{\mathrm{a}}$ binding efficiency to PvDBPII compared with Fy $\mathrm{F}^{\mathrm{b}}$. It has
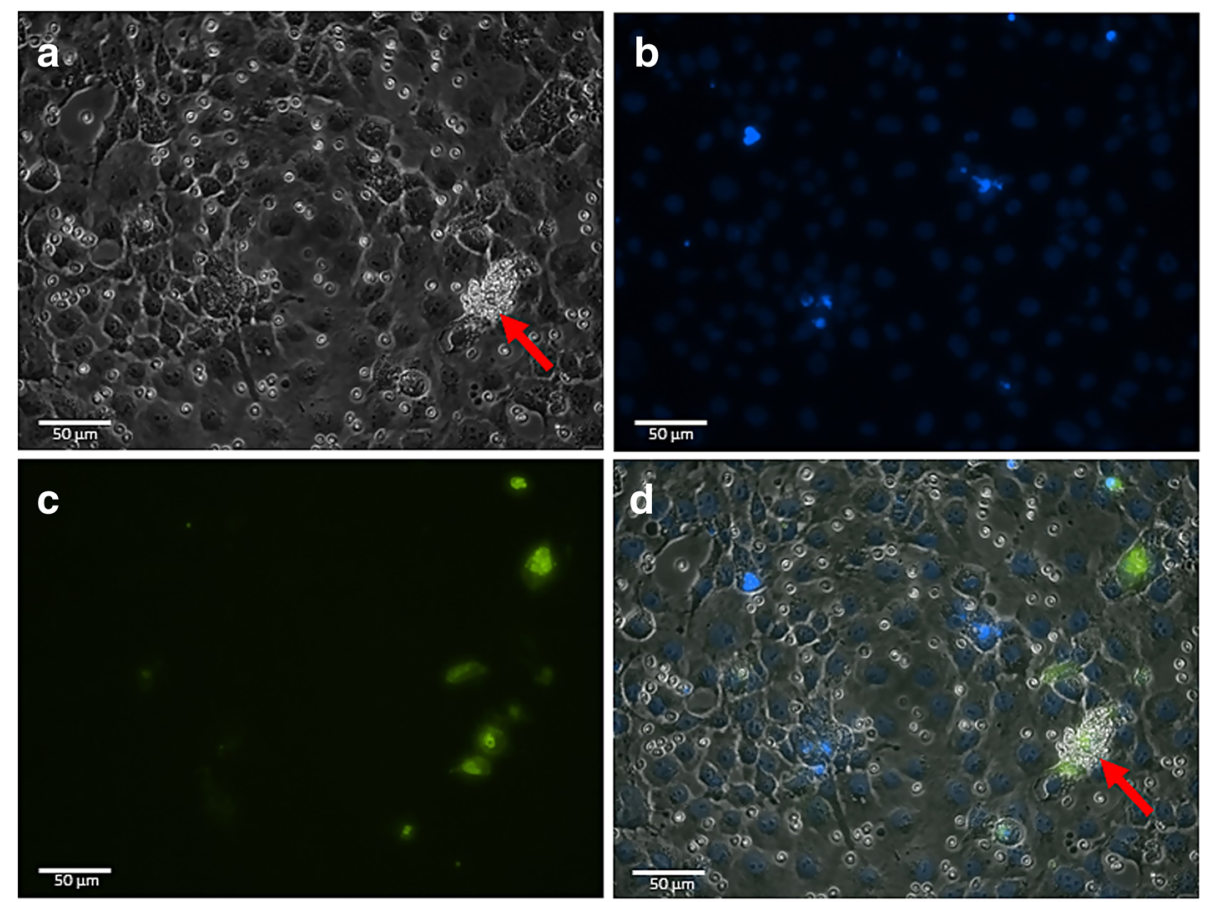

Fig. 1 Erythrocyte-binding assay to determine binding activity of PkDBPall to erythrocytes. a Rosette formation (red arrow) on PkDBPall-pDisplay ${ }^{\mathrm{TM}}$ transfected COS-7 cell, with more than 50\% of the cell surface covered by adherent erythrocytes. $\mathbf{b}$ Nuclei of COS-7 cells are stained blue with Hoechst dye. $\mathbf{c}$ Transfected COS-7 cells show green fluorescence indicating expression of GFP fluorescence tag and PkDBPall. $\mathbf{d}$ Merged images of $\mathbf{a}$, $\mathbf{b}$ and $\mathbf{c}$ showing the location of rosette, transfected cells and their nuclei 
Table 1 Erythrocyte-binding assays of PkDBPall using Fy ${ }^{a+/ b-}$ and $\mathrm{Fy}^{\mathrm{a}+\mathrm{b}+}$ erythrocytes

\begin{tabular}{|c|c|c|c|c|}
\hline Erythrocyte & Number of rosettes ${ }^{a}$ & t-statistic & $P$-value & Cohen's d $^{b}$ \\
\hline $\begin{array}{l}y=(n=2 \\
y^{a+/ b+}(n=\end{array}$ & $\begin{array}{l}94.75( \pm 23.16) \\
155.50( \pm 34.32)\end{array}$ & -2.935 & 0.026 & 2.075 \\
\hline
\end{tabular}

$\mathrm{Fy}^{\mathrm{a}+\mathrm{b}+}(n=4) \quad 155.50( \pm 34.32)$

${ }^{a}$ Number of rosettes [mean ( \pm standard deviation)] seen in 30 fields at 200 $x$ magnification

${ }^{b}$ Cohen's $d$ suggests that $d \leq 0.2$ is considered a small effect size, 0.5 medium effect size and $\geq 0.8$ large effect size

been implied that this decreased binding reduces the susceptibility of human individuals with an $\mathrm{Fy}^{\mathrm{a}}$ blood group to $P$. vivax malaria. Furthermore, increased expression of $\mathrm{Fy}^{\mathrm{b}}$ has been associated with an increase susceptibility to vivax malaria [8].

The only study that investigated PkDBP binding to Fy antigens was carried out almost 40 years ago [9]. The study used supernatant of in vitro cultured P. knowlesi as the source of PkDBP. The metabolically radiolabeled PkDBP from $P$. knowlesi culture supernatant that bound to erythrocytes was eluted and then analyzed by electrophoresis and autoradiography. The binding level was qualitatively determined by simply observing and comparing the intensity of $\mathrm{PkDBP}$ bands in the autoradiograph. In a related experiment in the study, the eluted radiolabeled PkDBP was used to probe membrane proteins from $\mathrm{Fy}^{\mathrm{a}}$ and $\mathrm{Fy}^{\mathrm{b}}$ erythrocytes that had been electrophoretically separated and transferred to nitrocellulose. Again, binding level was qualitatively determined by observing the intensity of bands in the autoradiograph.

In the present study, the binding level was quantitatively determined by counting the number of rosettes in the erythrocyte binding assay, and the difference in the mean number of rosettes obtained in the assays for $\mathrm{Fy}^{\mathrm{a} / \mathrm{b}+}$ and $\mathrm{Fy}^{\mathrm{a}+\mathrm{b}-}$ erythrocytes could be statistically tested. The results revealed that the mean number of rosettes obtained for $\mathrm{Fy}^{\mathrm{a}+\mathrm{b}+}$ was significantly higher than that obtained for $\mathrm{Fy}^{\mathrm{a} / \mathrm{b}-}$. Here, it can be surmised that the $\mathrm{Fy}^{\mathrm{b}}$ antigen contributed to the higher binding of the $\mathrm{Fy}^{\mathrm{a}+/ \mathrm{b}+}$ erythrocyte to PkDBP $\alpha \mathrm{II}$ compared with the $\mathrm{Fy}^{\mathrm{a} / \mathrm{b}-}$ erythrocyte, a feature which has also been observed in the binding of erythrocytes to PvDBPII [8]. This common feature can be explained by the fact that PkDBP $\alpha I$ and PvDBPII are orthologues which have similar critical domain and amino acid residues (Tyr94, Asn95, Lys96, Arg103, Leu168 and Ile175) for binding with Duffy antigen [14]. The difference in binding capacity of $\mathrm{Fy}^{\mathrm{b}}$ and $\mathrm{Fy}^{\mathrm{a}}$ to the parasites' Duffy binding protein, on the other hand, is likely attributed to the substitution of Asp42 in $\mathrm{Fy}^{\mathrm{b}}$ to Gly42 in $\mathrm{Fy}^{\mathrm{a}}$ [7].

Cross-sectional studies on Duffy antigen groupings in Brazil [15], Iran [16] and India [17] revealed a higher prevalence of $\mathrm{Fy}^{\mathrm{a}+\mathrm{b}+}$ in vivax malaria patients compared to healthy donors. It is believed that expression of the
$\mathrm{Fy}^{\mathrm{a}}$ and $\mathrm{Fy}^{\mathrm{b}}$ genes in conditional heterozygote enhances infection by $P$. vivax, thus rendering $\mathrm{Fy}^{\mathrm{a}+/ \mathrm{b}+}$ individuals more prone to infection. The question that now arises is: could the same could be true for knowlesi malaria? Hence, the next quest is to determine the prevalence of Duffy antigen phenotypes and knowlesi malaria in Malaysia and its surrounding countries.

\section{Conclusions}

The erythrocyte-binding assay has provided a simple approach to quantitatively determine the binding level of PkDBP $\alpha I I$ to the erythrocyte Duffy antigen. In this assay, $\mathrm{PkDBP} \alpha \mathrm{II}$ displayed higher binding to $\mathrm{Fy}^{\mathrm{a}+\mathrm{b}+}$ erythrocytes than to $\mathrm{Fy}^{\mathrm{a}+\mathrm{b}-}$ erythrocytes. Future studies need to be carried out to investigate whether the $\mathrm{Fy}^{\mathrm{a}+/ \mathrm{b}+}$ phenotype is associated with increased risk of acquiring knowlesi malaria.

\section{Abbreviations}

ASP-PCR: allelic specific PCR; $\mathrm{CO}_{2}$ : Carbon dioxide; DARC: Duffy antigen receptor for chemokines; DMEM: Dulbecco's Modified Eagle's medium; DNA: Deoxyribonucleic acid; FBS: Fetal bovine serum; FITC: Fluorescein isothiocyanate; GFP: Green fluorescent protein; PBS: Phosphate-buffered saline; PCR: Polymerase chain reaction; PkDBP: Plasmodium knowlesi Duffy binding protein; PVDBP: Plasmodium vivax Duffy binding protein

\section{Acknowledgements}

We thank the individuals who provided their blood samples for use in the erythrocyte-binding assay. We also thank Khai Lone Lim for helping in the construction of the PkDBPall-pDisplay ${ }^{\mathrm{TM}}$ plasmid.

\section{Funding}

This work was supported by the Fundamental Research Grant Scheme of the Ministry of Higher Education Malaysia (FP036-2015A) and the University Malaya Frontier Research Grant 2017 (FG015-17AFR). Both grants were awarded to MYF.

\section{Availability of data and materials}

All data generated or analyzed in this study are included in this published article.

Authors' contributions

MYF and YLL designed the study. FWC carried out the experiments. MYF and FWC wrote the manuscript. All authors read and approved the final manuscript.

\section{Ethics approval and consent to participate}

Ethics to use human blood samples and experiment procedures were approved by University of Malaya Medical Centre Medical Ethics Committee (MEC ref. no: 817.18). The volunteers gave their consent for the use of their blood in the study.

\section{Consent for publication}

Not applicable.

Competing interests

The authors declare that they have no competing interests.

\section{Publisher's Note}

Springer Nature remains neutral with regard to jurisdictional claims in published maps and institutional affiliations. 
Received: 27 April 2018 Accepted: 18 September 2018

Published online: 26 September 2018

\section{References}

1. Singh B, Kim Sung L, Matusop A, Radhakrishnan A, Shamsul SS, Cox-Singh J, et al. A large focus of naturally acquired Plasmodium knowlesi infections in human beings. Lancet. 2004;363:1017-24.

2. Moyes CL, Henry AJ, Golding N, Huang Z, Singh B, Baird JK, et al. Defining the geographical range of the Plasmodium knowlesi reservoir. PLoS Negl Trop Dis. 2014;8:e2780.

3. Iwagami M, Nakatsu M, Khattignavong P, Soundala P, Lorphachan L, Keomalaphet S, et al. First case of human infection with Plasmodium knowlesi in Laos. PLoS Negl Trop Dis. 2018;12:e0006244.

4. Millar SB, Cox-Singh J. Human infections with Plasmodium knowlesi zoonotic malaria. Clin Microbiol Infect. 2015;21:640-8.

5. Cowman AF, Tonkin CJ, Tham WH, Duraisingh MT. The molecular basis of erythrocyte invasion by malaria parasites. Cell Host Microbe. 2017;22:232-45.

6. Singh AP, Ozwara H, Kocken CH, Puri SK, Thomas AW, Chitnis CE. Targeted deletion of Plasmodium knowlesi Duffy binding protein confirms its role in junction formation during invasion. Mol Microbiol. 2005;55:1925-34.

7. Tournamille C, Le Van Kim C, Gane P, Cartron JP, Colin Y. Molecular basis and PCR-DNA typing of the Fya/Fyb blood group polymorphism. Hum Genet. 1995;95:407-10.

8. King $\mathrm{CL}$, Adams JH, Xianli J, Grimberg BT, McHenry AM, Greenberg LJ, et al. Fy(a)/Fy(b) antigen polymorphism in human erythrocyte Duffy antigen affects susceptibility to Plasmodium vivax malaria. Proc Natl Acad Sci USA. 2011;108:20113-8.

9. Haynes JD, Dalton JP, Klotz FW, McGinniss MH, Hadley TJ, Hudson DE, et al. Receptor-like specificity of a Plasmodium knowlesi malarial protein that binds to Duffy antigen ligands on erythrocytes. J Exp Med. 1988;167:1873-81.

10. Michon P, Fraser T, Adams JH. Naturally acquired and vaccine-elicited antibodies block erythrocyte cytoadherence of the Plasmodium vivax Duffy binding protein. Infect Immun. 2000;68:3164-71.

11. Cheng Y, Wang Y, Ito D, Kong DH, Ha KS, Chen JH, et al. The Plasmodium vivax merozoite surface protein 1 paralog is a novel erythrocyte-binding ligand of P. vivax. Infect Immun. 2013;81:1585-95.

12. Lim KL, Amir A, Lau YL, Fong MY. The Duffy binding protein (PkDBPall) of Plasmodium knowlesi from Peninsular Malaysia and Malaysian Borneo show different binding activity level to human erythrocytes. Malar J. 2017;16:331.

13. De Silva JR, Lau YL, Fong MY. Genotyping of the Duffy blood group among Plasmodium knowlesi-infected patients in Malaysia. PLoS One. 2014;9: e108951.

14. Singh SK, Hora R, Belrhali H, Chitnis CE, Sharma A. Structural basis for Duffy recognition by the malaria parasite Duffy-binding-like domain. Nature. 2006:439:741-4.

15. Cavasini CE, de Mattos LC, Couto AA, Couto VS, Gollino Y, Moretti $L$, et al. Duffy blood group gene polymorphisms among malaria vivax patients in four areas of the Brazilian Amazon region. Malar J. 2007:6:167.

16. Miri-Moghaddam E, Bameri Z, Mohamadi M. Duffy blood group genotypes among malaria Plasmodium vivax patients of Baoulch population in southeastern Iran. Asian Pac J Trop Med. 2014;7:206-7.

17. Monhaty SS, Singh KV, Fotedar R, Lakshminarayana J, Parihar R. Prevalance of Duffy blood groups among the population of the desert region of India. J Rural Trop Pub Health. 2011;10:53-6.

\section{Ready to submit your research? Choose BMC and benefit from:}

- fast, convenient online submission

- thorough peer review by experienced researchers in your field

- rapid publication on acceptance

- support for research data, including large and complex data types

- gold Open Access which fosters wider collaboration and increased citations

- maximum visibility for your research: over $100 \mathrm{M}$ website views per year

At BMC, research is always in progress.

Learn more biomedcentral.com/submissions 